\title{
UNIVERSITYOF
}

FORWARD

THINKING

WESTMINSTER用

WestminsterResearch

http://www.westminster.ac.uk/westminsterresearch

And For Law: Why Space cannot be understood without Law

Philippopoulos-Mihalopoulos, Andreas

This is a copy of the accepted author manuscript of the following article: PhilippopoulosMihalopoulos, Andreas (2018) And For Law: Why Space cannot be understood without Law. Law, Culture and the Humanities. The final definitive version will be available from the publisher Sage at:

https://dx.doi.org/10.1177/1743872118765708

(C) The Author(s) 2018

The WestminsterResearch online digital archive at the University of Westminster aims to make the research output of the University available to a wider audience. Copyright and Moral Rights remain with the authors and/or copyright owners.

Whilst further distribution of specific materials from within this archive is forbidden, you may freely distribute the URL of WestminsterResearch: ((http://westminsterresearch.wmin.ac.uk/).

In case of abuse or copyright appearing without permission e-mail repository@westminster.ac.uk 


\section{And For Law: Why Space cannot be understood without Law}

\section{Andreas Philippopoulos-Mihalopoulos}

The Westminster Law \& Theory Lab, Westminster Law School, University of Westminster, London, UK

4-12 Little Titchfield Street, London, W1W 7UW

andreaspm@westminster.ac.uk

Andreas Philippopoulos-Mihalopoulos, LLB, LLM, PhD, is Professor of Law \& Theory at the University of Westminster, and founder and Director of The Westminster Law \& Theory Lab. His interests are typically interdisciplinary, including space, corporeality, new materialism, and philosophy. Andreas also pursues an artistic practice under the name of picpoet. Edited volumes include Law and the City (2007), Law and Ecology (2012), Luhmann Observed: Radical Theoretical Encounters (2013), and with Augusto Cusinato Knowledge-Creating Milieus in Europe (2015). He has published three monographs, Absent Environments (2007), Niklas Luhmann: Law, Justice, Society (2010), and Spatial Justice: Body, Lawscape, Atmosphere (2014). Andreas is the editor (with Christian Borch) of the Routledge Glasshouse series Space, Materiality and the Normative. 


\section{And For Law: Why Space cannot be understood without Law}

\section{Andreas Philippopoulos-Mihalopoulos ${ }^{1}$}

Doreen Massey, the iconic political geographer, whose book For Space has influenced the way various disciplines understand space, has largely ignored law in her work. In fact, most non-legal scholars replace law with politics. Here, I read Massey through law, arguing that often, non-legal writing is characterized by a misapprehension of the law. Through an analysis of her arguments against some understandings of space (such as systemic, negative, closed, textual), I mount a critique against the standard understandings of law (as precisely all these things) and suggest instead a lawscaping way of understanding the connection between law and space, as well as issues of spatial justice and responsibility.

Keywords: Doreen Massey; law; space; justice; responsibility; lawscape

\section{Where is Law?}

Doreen Massey is one of the most important geographers of our time. Her work on politics of space, gender, globalization and community has had a profound impact, to the extent that Massey is thought to be the principal originator of political geography ${ }^{2}$ and "the most

1 With thanks to Julia Avila Franzoni, Sharron FitzGerald, Phil Hubbard and the anonymous reviewers for their perspicacious suggestions.

${ }^{2}$ David Featherstone and Joe Painter, eds, Spatial Politics: Essays for Doreen Massey (Oxford: Blackwell, 2013). 
systematic philosophical geographer" across the ages. ${ }^{3}$ Her theoretical and applied work on the concept and practice of space has been extremely influential in the way space is understood, not just by geography but by all disciplines. She has managed to move the discourse, from the old conceptions of space as container, essentialized abstraction, or its positivist, quantifiable understanding, to an open concept of space that is connected, relational, embodied, gendered, processual, contingent, multiple and often paradoxical. She has ushered a by-now fully accepted understanding of space in the vocabulary of multiple disciplines, including law, opening thus the way for the emergence of a legal geography of contingency and connectedness.

Despite her formidable interdisciplinary credentials, Massey has hardly ever dealt with the law in her writing. Such an omission becomes even more baffling when one brings in Doreen Massey the person: during my friendship with her, the law had often emerged in our conversations. Her deep problematizing of the law, her frustrated dealings with it, but also her profound mistrust of its potential were all frequent topics of our discussion. In her work, however, references to the law are scarce; and then only in terms of 'rights' or 'regulation', or administrative structures of the Greater London Authority which broadly fall in some legal category. But to make a meal of this would be inconsistent with the general thrust of Massey's work. Indeed, her whole authorial stance is not just indifferent to the law but a move away from law, even anti-law. Law seems to be representing everything that Massey cannot accept: abstract, closed, textual, hegemonic, orderly, apolitical, and so on.

\footnotetext{
${ }^{3}$ Arun Saldanha, "Power-Geometry as Philosophy of Space", in Spatial Politics: Essays for Doreen Massey, Featherstone and Painter, eds., (Oxford: Blackwell, 2013), p. 48.
} 
It is hard for us, as legal academics, to understand how law appears to non-legal academics, but the above characterizations are not uncommon. There might be good reasons for this: legal terminology is less integrated in everyday language than say that of geography, psychology or even science, and therefore less familiar; jurisdictions and scale, different traditions of Common Law, Roman Law, Indigenous law and so on, variances in enforceability and legal qualities (formal/informal, written/oral, state law/general normativity, and so on), all contribute to the perceived impermeability. Terminology apart though, the law often appears to be irrelevant (abstract, closed, textual, hegemonic, orderly, apolitical) when compared to the immediacy of political struggles. It seems too slow for the urgency of geopolitical and ecological issues, and too co-opted for anti-hegemonic thinking. And it can be summarily replaced by something which is more approachable, less prohibiting in terms of language, ostensibly more flexible and quotidian: politics. While such a substitution is understandable in view of politics' allpermeating rhetoric and presence ('everything is political', 'the private is political' etc), the velocity with which it feeds into media's need for constant new developments, and its implicit inclusion of the law, there is a vast amount of issues missed, marginalized or plainly misunderstood when the law is not explicitly dealt with.

This is particularly important for geography: to exclude law when thinking of issues of property, boundaries, the distinction between public and private, new hybrid spaces of private-public partnerships, territory, conflict, order, geopolitics, and even space itself as a whole, is to reduce them to versions of political issues that take place in space, but whose conceptualization, determination, justification, duration and enforcement remain devoid of a convincing explanation. This is not just a question of origin: there is little doubt that law is involved in the imposition of boundaries, and that 
subsequently boundaries are enforced by law. ${ }^{4}$ But the determining influence of law extends beyond an originary act. It permeates every single iteration of geographical phenomena, reinforcing them, modifying them or annulling them, helping geographers (and others) explain the world.

Naturally, some disciplines are more open to the law than others. International relations, policy studies, business administration, amongst others, routinely include legal analyses. Similarly, some takes on law have crossed existing disciplinary boundaries with relative ease. Law in action, for example, offers a much more palatable version of the law as instrument of social transformation, and has been introduced in international relations, history, and policy studies, amongst others. ${ }^{5}$ The broad umbrella of sociolegal studies enjoy wide acceptance when it comes to politics, sociology, economics and so on. This does not mitigate the fact, though, that the law is not as pivotal for other disciplines as, say, politics or economics. Non-legal scholars working on law are still a rarity, especially when it comes to its more theoretical perspectives. This is perhaps the reason for which legal geography, however successful in creating new ways of thinking about the law, is not as widely studied as, say, law and economics. Law's empirical aspect is often integrated in other disciplines as regulation; law's theoretical aspect, however, remains largely unknown outside legal scholarship. Legal geography has always been aware of

\footnotetext{
${ }^{4}$ Julia Chryssostalis, "Reading Arendt 'reading' Schmitt: Reading Nomos Otherwise?", in Feminist Encounters with Legal Philosophy, Drakopoulou, ed. (London: Routledge, 2013).

${ }^{5}$ See, however, how the distinction between that and law in books is too facile: JeanLouis Halperin, "Law in Books and Law in Action: The Problem of Legal Change,"
} Maine Law Review, 64(45) (2011), 45-76. 
the need to bring in the theoretical, ${ }^{6}$ and this has complicated its reception even further. In that sense, it too has failed to address law's impression of inaccessibility.

My goal in this text is double: first, to address the need for an 'exportable' understanding of the law, namely a law that is neither weighed down by the terminological freight of empirical application, nor clouded by excessive theorization (whether positivist or critical) that cannot be understood outside the law. In order to do this, I address some of the misconceptions of what the law is, and in their stead I offer a grounded way of understanding the law. To do this, however, I need the concept of geographical space, and for this reason I focus on the discipline of geography, and specifically its most sustained inquiry into space, namely Massey's 2005 book For Space. The claim I am making here is that law is entrenched in everything that takes place in

${ }^{6}$ see indicatively Irus Braverman et al., eds., The Expanding Spaces of Law: A Timely Legal Geography (Stanford: Stanford University Press, 2015); Nicholas Blomley, Law, Space, and the Geographies of Power (New York, NY : Guilford, 1994); David Delaney, "Beyond the World: Law as a Thing of this World,' in Holder and Harrison, eds, Law and Geography (Oxford: Oxford University Press, 2002); Benjamin Forest, "The Legal (de)construction of Geography: Race and Political Community in Supreme Court Redistricting Decisions", Social and Cultural Geography 5(1) (2004), 55-73; Phil Hubbard, et al., Thinking Geographically: Space, Theory and Contemporary Human Geography, (London Continuum, 2002); Gill Valentine and Catherine Harris, "Encounters and (in)tolerance: Perceptions of Legality and the Regulation of Space", Social and Cultural Geography 17(7) (2016), 913-932; Andreas PhilippopoulosMihalopoulos, Spatial Justice: Body, Lawscape, Atmosphere (London: Routledge, 2014), subsequently Philippopoulos-Mihalopoulos, Spatial Justice. 
geographical space (to wit, everything), and that a recourse solely to politics instead of also law, deprives geography of indispensable insights in the phenomena at hand in relation to both their origin and evolution. I attempt to think of Massey's space, and this is the second aim of this article, in parallel to law, thus adding the jurisprudential dimension to Massey's analysis. ${ }^{7}$ This is relevant for both legal scholars and geographers, as well as for those in the transdisciplinary space of various other disciplines: law can open up Massey's grounded thought on space to considerations of legality, while geography can see law as approachable, and indeed no longer inscrutable.

\section{For Space, Against Law}

Massey looks at space from both an abstract, philosophical perspective and as an empirical action field. She understands it in both its universality and its particularity, although she is quick to reject the former, and replace it with an understanding of connectivity that radiates everywhere. Space for Massey, and perhaps for geography as a

\footnotetext{
${ }^{7}$ To my knowledge, no attempt at reading Massey's work through a legal lens has been attempted so far; see however Sarah Keenan, Subversive Property: Law and the production of spaces of belonging (London: Routledge, 2015), and S. Bond and S. Kindon, 'Working with Doreen Downunder: Antipodean Trajectories', in Spatial Politics: Essays for Doreen Massey, David Featherstone and Joe Painter, eds. (Oxford: Blackwell, 2013) on indigenous law and Massey.
} 
whole, is what law is for legal scholars: elusive, paradoxical, multiple, and always running the risk of becoming essentialized and thus misunderstood. Yet law's melancholic lawyer ${ }^{8}$ is replaced by Massey's considerably more upbeat political geographer. Massey embarks upon a philosophical journey of constructive critique, starting from structuralism and representation, moving on to deconstruction, to Laclau and Mouffe, and finally Bergson and what is broadly understood as Deleuzian thought. She does this with a strong emphasis on gendered and grounded thinking, and concludes with her by now deeply influential formulation of space as the product of interrelations; as the sphere of the possibility of the existence of multiplicity; and as a process, always under construction. ${ }^{9}$ As we shall see, this definition provides ample space for including legal narratives in the definition of space. ${ }^{10}$

Massey critiques the ways in which space has been theorized in the literature (especially space as container, representation, subsumed to time or textual narratives), offering in their place a materially grounded yet theoretically adventurous understanding of space. Her definition eschews essentialization while at the same time attempts to be all-informing and flexible. What is remarkable for my purposes, however, is that these criticisms are similar to the ones launched against what is called 'positivist', 'doctrinal', 'black-letter' law - namely, the way most of us imagine the law before really dealing with it. This law is often seen as an inflexible text that commands and controls, in close

\footnotetext{
${ }^{8}$ Peter Goodrich, Oedipus Lex (Los Angeles: University of California Press, 1995).

${ }^{9}$ Doreen Massey, For Space (London: Sage, 2005), p. 9ff. Subsequently Massey, For Space.

${ }^{10}$ see e.g. Marianne Constable, Our Word is Our Bond: How Legal Speech Acts (Stanford CA: Stanford University Press, 2014).
} 
connection to a historical understanding of time (in the form of tradition, inherited structures, and legal precedent), and barricaded behind an impermeable legal language. I would like to explore these commonalities between space and law as objects of critique, and draw some parallels between Massey's critique and the law.

The main reason for which Massey criticizes and partly rejects ideas of space as representation is because "over and over we tame the spatial into the textual and the conceptual; into representation". ${ }^{11}$ Taming space is a recurrent theme in Massey's work and one that causes her palpable irritation because it mutes what space is really about. Taming space causes "the suppression of what [space] presents us with: actually existing multiplicity". ${ }^{12}$ Taming space is regularly done through a textuality that reduces the multiplicity of narratives (a defining characteristic of space for Massey) into a "business of lying things out side by side". ${ }^{13}$ Unsurprisingly, textuality is also law's defining characteristic. Law revolves around acts and statutes, cases and court decisions, written and unwritten principles that are set up through language, and whose status and relevance are consistently determined by language. The ultimate aim of law's textuality is precisely to 'lie things out side by side': to flatten out the complexity of reality and convert it into admissible legal facts, on the basis of which a decision can be taken. Textuality, therefore, is law's main tool of representation. Reality is represented, indeed translated into, legal language. Acting on a need to eat despite having no money to buy food, is irrelevant to the law, unless translated into a legal event that would involve illegal possession through theft. Law does not deal with reality but with a legal representation of reality - it seems

\footnotetext{
${ }^{11}$ Massey, For Space, p. 20

${ }^{12}$ Massey, For Space, p. 69

${ }^{13}$ Massey, For Space, p. 27
} 
that this is the only way in which the law can be meaningful. This means that the thief's hunger might be considered in law as some form of extenuating circumstances - but they too would have to be translated into law, and would not alter the nature of the unlawful act. $^{14}$

Textuality is part and parcel of what Massey critically refers to as the 'negativity' of deconstruction. As is well known, deconstruction took up structuralism's linguistic structures and turn them onto their head through such interventions as différance, supplement, aporia and so on. ${ }^{15}$ Jacques Derrida's phenomenological provenance, however, despite its undoubtedly revolutionary effect on contemporary thinking, is built around distinctions, fragmentations and ruptures, namely impasses that open negative spaces of impossibility. Of course, negativity in deconstruction is an inherently productive force; yet when contrasted (as Massey does) with something like the positivity of plenitude that comes from such thinkers as Spinoza, Nietzsche and Deleuze, deconstructivist negativity remains a space of impasse. For Massey, deconstructivist negativity takes otherness away from Derridean spacing. Massey, for whom otherness as inclusion of difference is paramount for space, links spacing with "rupture, dislocation, fragmentation and the co-constitution of identity/difference". ${ }^{16}$ Massey's critique of negativity as "both politically disabling and problematical for a rethinking of the

${ }^{14}$ Costas Douzinas, “Identity, Recognition, Rights or What Can Hegel Teach Us About Human Rights?”, Journal of Law and Society 29(3) (2002), 379-405.

15 Jacques Derrida, Of Grammatology, trans. G. C. Spivak, (Baltimore: John Hopkins University Press, 1997).

${ }^{16}$ Massey, For Space, p. 51 
spatial" 17 would not sound alien if it were to be applied to law. To start with, law operates with a space of negativity in its conceptual core. This is because law is a paradox. It deals with lawfulness while relying axiomatically on its own presumed lawfulness. But is law lawful? This is the question the law should never ask because there is no possibility of external justification. Law is perforce 'lawful', immanently and axiomatically, because otherwise it could not justify its existence. ${ }^{18}$ At best, it draws its legitimacy from the exercise of 'lawful' (state) violence, of which it retains the monopoly. ${ }^{19}$ In other words, law must keep its foundations in the dark, in the negative space of blind-spots and foundational taboos, if it is to carry on. Negativity is part of law's everyday operations too: it must distinguish between lawfulness and unlawfulness, indeed guilty and not guilty. Mark, not guilty and 'innocent' ${ }^{20}$ Neither outcome is characterized by positivity. At best, it is a question of minimizing negativity ('not guilty'). Negativity characterizes law also socially: law is usually the last resort, the pit of negativity, when nothing else has worked or is expected to work.

Law operates through rupture and exclusion as a matter of course. One of the things that law ruptures and fragments is reality. The various narratives of the people who

\footnotetext{
${ }^{17}$ Massey, For Space, p. 51
}

${ }^{18}$ Niklas Luhmann, Law as a Social System, trans. K Ziegert (Oxford: Oxford University Press, 2004)

19 Jacques Derrida, "Force of Law: The 'Mystical Foundation of Authority", trans. Michael Quaintance, in Deconstruction and the Possibility of Justice, Cornell, Rosenfeld and Gray Carlson, eds. (New York: Routledge, 1992).

${ }^{20}$ Andreas Philippopoulos-Mihalopoulos, "Giving Guilt: The Aneconomy of Law and Justice”, Distinktion: Scandinavian Journal of Social Theory, 12(1) (2011), 79-93. 
come to or are called by the law, are submitted to a process of legal analysis and indeed fragmentation, excluding irrelevant facts and retaining only the ones that can be converted into legally ingestible bites. For this reason, law habitually excludes politics. This initially might appear counter-intuitive, but it is important to understand that law is not politics. What is law (and why it is not politics) follows immediately below, but the idea of exclusion of politics from law is an integral part of the legal identity. In a universally and equitably applied law, political biases are just that and must be avoided if the neutrality and objectivity of the law is to remain beyond reproach. Abstraction, textuality and representation, in a comparable way to their legal equivalents, are "characteristics which, to my mind at least, disable [space's] full insertion into the political". ${ }^{21}$ Law must remain apolitical if it is to retain (the allure of) objectivity.

In so doing, however, law perpetuates its closure, namely its epistemically fortified boundaries that determine what law is, and how it differs from, say, politics or economics. A full discussion eschews the ambit of this article, but it is important to explain at least some elements of this legal closure. Following Niklas Luhmann's analysis, ${ }^{22}$ which is arguably the most complete exposition of legal closure, the law is a normatively closed system, for which other disciplines/systems (such as politics, media, economics, religion and so on) have no relevance except if and when converted into legal language. For this to happen, a question must arise: is this event/act/object lawful or unlawful? Until then, nothing is registered by law. But once this question pops, law 'wakes up' as it were, and begins its operations. Even then, however, law does not open up to other systems. It merely deals with issues that other systems might be dealing with

\footnotetext{
${ }^{21}$ Massey, For Space, p. 17

${ }^{22}$ Luhmann, Law as a Social System.
} 
at the same time, from their own perspective and language. This is because each system in society has its own distinct function. Thus, law's function is to bind the expectations that society has of what is and what is not lawful: in short, what to do and what to avoid. Expectations need to remain stable, and are not to be frivolously betrayed, if law is to remain relevant. Theft is to remain unlawful, whatever the circumstances. In this way, society will evolve, safe in the knowledge that property is protected by law. This means that, although the law changes, it does so incrementally and usually conservatively. This is also because legal change, just as any other legal operation, is a product of closure and not of direct influence from, say, politics or economics. If that were the case, then we would be talking about a totalitarian or corrupt society, where no separation of powers were in place. Let me take the example of an act of terrorism, an event that emerges in various systems with considerable force. It is taken up by the media, it is used by politics as a way of persuasion, it impacts global markets, it even reopens questions of religion if it was perpetrated by a religious fundamentalist. It is also taken up by law to assess whether indeed it was an act of terrorism, who the culprits were, and so on. There is crossfertilization among the various systems and their takes on the same act, but each system advances on its own temporality and according to its own function, and might well reach different outcomes (thus, the act might not have been legally speaking an act of terrorism, but the media's take on it will have already created such a social panic that markets will have collapsed, and potentially catastrophic political decisions will have been taken in haste).

Both system and closure are anathema for Massey when it comes to space. System is understood in the 'systematic' way, as the superimposed structure that organizes space and movement in an orderly way thus trying to contain the inherent unpredictability of space. Likewise, "closure itself robs 'the spatial' (when it is called such) of one of its 
potentially disruptive characteristics: precisely its juxtaposition, its happenstance arrangement-in-relation-to-each-other, of previously unconnected narratives/temporalities; its openness of always being made." 23 It is fair to say that closure attracts Massey's heftiest critique, largely because she understands closure (not unjustifiably) as something that fixes and coagulates ("space as always in process, as never a closed system" p 11), that keeps space locked up ("I hope to liberate 'space' from some chains of meaning (which embed it with closure and stasis...)" (p 19), and that formalizes things in ways that do not accord with life ("an order imposed upon the inherent life of the real" p 30). Closure is also associated with static synchronicity (p 38) and sealed causality ( $\mathrm{p} 43$ ), where "the closed system is the foundation for the singular universal" ( $p$ 55). Massey's vituperative critique of closure is not out of place in the context of the references she uses. Spatial closure cuts off connections between places, while constructing a fake causal connectivity of all points included within, perpetuating in this way the colonial process of rejecting everything that does not fit the closed vision of the world.

This list of theoretical constructions of space against which Massey writes could carry on. The point is not to offer an exhaustive list but to explore the potential parallels between these and some of the characteristics frequently attached to law, as I have shown above. The parallels are not accidental. Space and law are co-constituting, and so are theories about them. The omission to deal with the law has this remarkable effect: we are presented with the outcomes of the law's presence in space, but not the causes. Ideas of space as representation, text, abstraction, system and closure, I argue, all come from a juridical understanding of space. Not only does law understand space in the above ways,

${ }^{23}$ Massey, For Space, p. 39 
but also, this specifically legal way of understanding space affects the way other disciplines understand space as well. To take it even further, law intervenes before the various theoretical constructions, and renders space a legal construction. This is because law has always already intervened, right from 'the start', when a line was drawn for the first time to distinguish 'mine' from 'yours'. Law is 'the first distinction', ${ }^{24}$ a line carved on the ground with a twig, to show where the other should stop and where I should be able to feel free to roam. Which came first, whether law or line, is a matter of pedantry. They mutually reinforce each other, especially once, as Tim Ingold writes, lines were to be drawn with a ruler:

\begin{abstract}
"A ruler is a sovereign who controls and governs a territory. It is also an instrument for drawing straight lines. These two usages ... are closely connected. In establishing the territory as his to control, the ruler lays down guidelines for its inhabitants to follow. And in his political judgements and strategic decisions - his rulings - he plots the course of action they should take. As in the territory so also on the page, the ruler has been employed in drawing lines of both kinds." 25
\end{abstract}

Even before the use of the ruler, however, lines brought about the law of the land. In aboriginal spaces, law has always been synonymous with land and land with law. ${ }^{26}$ The

\footnotetext{
${ }^{24}$ Luhmann, Law as a Social System.

${ }^{25}$ Tim Ingold, Lines: a Brief History (London: Routledge, 2007), p. 161.

${ }^{26}$ Christine Black, The Land is the Source of the Law: A Dialogic Encounter with Indigenous Jurisprudence (London: Routledge, 2011).
} 
movement of bodies in space constructed the laws with which the body would move, marking space in a form that has always been co-extensive with law.

So why is there no law in Massey's analysis of space? I would like to suggest that there is law but is hidden away. Law represents Massey's fear that space is losing its political dimension and indeed its spatiality. In an instructive, parenthetical passage (instructive also because parenthetical) she writes: "(The effect of the application of 'rules' is that, as with the assertion of the inevitability of globalisation, it takes politics out of the debate. It treats the process of globalisation as a technical matter)". ${ }^{27}$ So 'rules' kill politics. 'Rules' are clustered together with 'technical matter' and, appearing later in the text, "the order of the market". ${ }^{28}$ They are all, in some form, law, and they are all thought to have the same depoliticizing effect. Depoliticization of space is part of a larger, more serious movement that aims at taming space: "much 'spatial politics' is concerned with how such chaos can be ordered, how juxtapositions may be regulated, how space might be coded, how the terms of connectivity might be negotiated. Just as so many of our accustomed ways of imagining space have been attempts to tame it."29 "Ordered", "regulated", "coded", "negotiated": one could hardly think of more deeply juridical verbs, all in the service of 'taming' space, making it flat, horizontal, synchronous, apolitical, in

\footnotetext{
${ }^{27}$ Massey, For Space, p. 103

${ }^{28}$ Massey, For Space, p. 112

${ }^{29}$ Massey, For Space, p. 152
} 
short: aspatial. ${ }^{30}$ Space deprived of its fundamental characteristics of interrelations, multiplicity and process is no longer space.

Just as law fears space, as I have argued elsewhere, ${ }^{31}$ in the same way space fears law. Just as law despatializes space and makes it all law, space invalidates law and makes it all politics. Referring to public space, Massey writes: "all spaces are socially regulated in some way, if not by explicit rules (no ball games, no loitering) then by potentially more competitive (more market-like?) regulation which exists in the absence of explicit (collective? public? democratic? autocratic?) controls." 32 This admittance on the one hand of the all-pervading presence of regulation (even if qualified by the adverb 'socially'), and the total absence of analysis of the role of law on the other, can only mean one thing: that space is afraid of the law because of the latter's potential despatializing effect through order, codes, rules and all the other known artifices of law. It reads, therefore, like denial when Massey gives Chapter 14 of For Space the title: "there are no rules of space and place". ${ }^{33}$ Massey knows that there are rules everywhere, but she prefers to avoid this potential conflict between spatial politics and law. In a passage referring to the gaping disparity between the City of London and the rest of the city, she writes "it is a conflict which is usually hidden. Indeed the real difficulty is that lack of recognition." ${ }^{34}$

\footnotetext{
${ }^{30}$ see also Doreen Massey, Power-Geometries and the Politics of Space: Hettner Lecture 1998 (Heidelberg: University of Heidelberg, 1999) on how globalization renders space aspatial.

${ }^{31}$ Philippopoulos-Mihalopoulos, Spatial Justice.

${ }^{32}$ Massey, For Space, p. 152

${ }^{33}$ Massey, For Space, p. 163

${ }^{34}$ Massey, For Space, p. 157
} 
At the risk of sounding as if I am indulging sophistry, I would insist that conflict (which might emerge in politics but is regulated and ultimately resolved, if at all, by law) is not as pronounced in Massey's work as it could be. Conflict appears only occasionally, usually when Massey discusses Chantal Mouffe's agonistic politics. ${ }^{35}$ Conflict and its potential are not analyzed with the same rigor as other concepts, nor is it understood as anything more than political. But conflict is intimately connected to law. As a result, the role of the latter is marginalized. To put it differently, Massey demotes conflict and law from priorities, in her preference over a concept of space that emphasizes interrelations, multiplicity and process. This is a laudable attempt to reimagine space away from a Schmittian line drawn by a ruler and the ubiquity of nomic conflict, and towards space as emergence, relationality and open-endedness; but what is left outside is too important. Significantly, by marginalizing law, this approach leaves out a whole different understanding of space.

\section{Another Law: the Lawscape}

There is another law. This other law includes closure and text and even negativity. Yet, at the same time, it is folded in with space; it is intimately connected to matter, bodies and movement, often (but by no means always) converting this connection into textual representation; and it accepts negativity within a much ampler, positive plenitude. There is another law that functions along space, folding and unfolding while eavesdropping on

\footnotetext{
${ }^{35}$ Chantal Mouffe, On the Political (London: Routledge, 2005).
} 
spatial operations. In what follows, I would like to suggest a way of thinking about law that is not removed from space, nor evokes the various negative geographical critiques in the way a more traditional understanding of the law would. This other law is not necessarily prohibitive, exclusionary or hierarchical (but it can also be that). Its intimate connection with space means that it is perfectly aware of its spatiality, and understands its operations to be stemming from and returning to it.

This other law, I have called the lawscape. ${ }^{36}$ The lawscape is a way of thinking of the tautology between law and space. Lawscape is both another law, and another space. It is a response to the doctrinal, black-letter forms of law and legal thinking that habitually ignore spatial considerations; and a way of doing away with such preconceptions of law as abstract, universal, immaterial and incorporeal. It is also a response to geography that has found comfort in politics but has shied away from law. In other words, it is a way of sympathizing with and responding to Doreen Massey's fears of law, not by allaying these fears but by suggesting another way of seeing the law. In this suggestion, however, there is something else too: in what follows, I show how fears of law cannot be easily separated from fears of space itself. That is, when there is fear of law, there is also fear of space. This fear refers to the possibilities, inherent in space, to become closed and negative, inescapably conflictual and given to technical, textual negotiations. In other words, to become 'legalized', asphyxiatingly settled and without the possibility of real positivity. ${ }^{37}$

I would like to suggest here that space can be all that stuff and yet remain spatialized and political. I further suggest that closure, textuality and negativity are even

\footnotetext{
${ }^{36}$ Philippopoulos-Mihalopoulos, Spatial Justice.

37 This is what, in my Spatial Justice book, I have described as engineered atmosphere, namely the asphyxiatingly constructed environment that directs desire in specific ways.
} 
necessary instances of space (and law). It is all a matter of degree: how much closure is enough? How much of a system must space be, in order to allow flow and future? How much textuality can space entertain without losing its positive accommodation of otherness? The degree of difference is determined by law. Law allows for a certain amount of closure, say in terms of locking up one's own property door at night; or determining who will be able to cross one's patch of land and under what conditions. But it also allows Hungary to shut off its boundaries to Syrian and other refugees, as it has happened in 2016-17. So what kind of closure and openness are we to accept and what to condemn? As Massey writes

\footnotetext{
"the real socio-political question concern less, perhaps, the degree of openness/closure...than the terms on which that openness/closure is established. Against what are boundaries erected? What are the relations within which the attempt to deny (and admit) entry is carried out? What are the power-geometries here; and do they demand a political response?"38
}

To this, I would add the demand for a legal response too, and legal negotiations during which the terms are established. The possibility of erecting boundaries is not always undesired - but when is the exclusion that inevitably results from boundaries excessive or plainly noxious and ethically reprehensible? This is a question of the lawscape, and the negotiations that take place in it.

${ }^{38}$ Massey, For Space, p. 179 
I define the lawscape as the way the tautology between law and space unfolds as difference. We begin with tautology: for what is space without law or law without space? Space without law is a fantasy of pure possibility, some utopia where everything is settled because there is no difference, therefore no conflict. Space without law is a nullifying expanse where no body can ever move from its assigned position, because, if it did, it would create a distinction (indeed, a law) between before and after, here and there, movement and pause, indeed a way to do this, followed later by others until it becomes fixed as law. In the same vein, law without space is another fantasy of law as a universal, floating above spatial differences, obeying to some natural or theological necessity, but never really scooping down to apply itself to the situation in hand. So, law and space are folded into each other: they are co-emerging, co-constituting and co-evolving.

We carry on with difference, the space of negotiations. For various epistemic and ontological reasons, the tautology often needs to be broken open. Epistemologically, as a means of focus that demands higher and more specialized detail, one excludes one or the other. Ontologically, more importantly, there is a need to take a distance from the sheer weight of the realization that law and space are tautological. We all need to forget about the law. We cannot be thinking about the law when we walk around a city, go for shopping, or switch on our TV to relax in the evening. We cannot be constantly thinking of ours and others' legal obligations (by-laws, tort issues, contractual risks, environmental legal thresholds, EU law directives, international law obligations - despite their often having a direct impact on our everyday movements) when we are not, say involved in a legal case or contemplating legal action or being caught during a potentially illegal act. Space as interrelation and multiplicity requires the possibility of crossing boundaries. It also requires forgetting the fact that, in the act of crossing, one always generates new 
boundaries and therefore laws. Space (as difference, flow, process) requires an invisibilization of the law, if only temporarily.

Law also needs to invisibilize space. While permanently forgetting about space ends up in the usual time-and-history-led, ungrounded, incorporeal and immaterial accounts of law as abstract and universal, a temporary invisibilization of space for law can be useful. As mentioned earlier, law's function is to bind social expectations that will not change arbitrarily or flippantly. Law needs to maintain the allure, even illusion, of stability despite temporal and geographical differences, because only in this way can the law nourish the narrative of its impartiality. This does not mean that law is not impartial. Nor, however, that it is. It might be, and it might not be impartial. The point is that law needs to retain its function as a final and neutral arbiter by maintaining also the narrative that goes with it - and to do this, law often needs to invisibilize space, make it less of a threatening factor to its universal appeal.

If, therefore, the lawscape is the way law and space unfold as difference, this unfolding takes place through invisibilization of either one of them, depending on the conditions. This invisibilization is not absolute. Rather, it is a matter of negotiations. Each body (human and nonhuman, individual and collective) that participates in the lawscape, negotiates its movement and the space generated, in relation to other bodies, and depending on the conditions, determines (not necessarily consciously) the degree of invisibilization of law or space. It is a body's predicament to distance itself from either law or space, in order to facilitate its movement or pause (say, to choose to forget that a shopping mall is not just a consumerist heaven but also a place that excludes bodies that do not fit in, activities that interfere with shopping, climatological conditions that impede moving from shop to shop etc). Of course, there are bodies that are much stronger than others, making the whole movement skewed. This is where the law re-emerges in the 
lawscape and makes sure that, however much political power (in the body of an irresponsible head of state, multinational corporations, the local bully) wants to push things in a certain direction, the law will erect boundaries and resist. Not always of course, and not necessarily in a satisfactory way, but often with some measure of success.

There is always a degree of law in spatial narratives (and vice versa) as we have seen in Doreen Massey's work. But it gets covered up, hidden under the guise of politics or generic notions of regulation. These are all degrees in which space invisibilizes law. As I have mentioned earlier, however, the degree of invisibilization in the case of Massey's writing is indicative of a considerable fear towards law that is not merely about impermeable terminology but very specifically about a misunderstanding of what the law is (and I am referring here generally to geography, whose branch of legal geography is rather isolated and has not managed to capture the geographical imagination in the same way as, say, political geography has).

Fearing law, however, is also fearing space - at least an aspect of space that relational theories marginalize. ${ }^{39}$ This is the aspect of space as closed, textual, negative and systematic. As I have shown above, while law is not just these things (there is another law), it is also these things, more than most other disciplines. The lawscape of coemergence of law and space can only mean one thing: not just law but also space can be closed, textual, negative and systemic. At the very least, it is the space within the ambits of traditional, black-letter law (namely, the way traditional law understands space) where

\footnotetext{
${ }^{39}$ but also non-representational theories, and other theories that have been influenced by Deleuzian thought, e.g. Nigel Thrift, Non-Representational Theory: Space | Politics | Affect (London: Routledge, 2007); Marcus Doel, Poststructuralist Geographies: The Diabolical Art of Spatial Science (Edinburgh: Edinburgh University Press, 1999).
} 
space is converted into jurisdiction, territory, property and so on. This means that space is never just smooth, to use the Deleuze/Guattarian terminology, but always simultaneously striated. This, Massey knows well, and indeed presents her project as a revolt against the by now stale geographical imagination of space "as already divided-up, of places which are already separated and bounded". ${ }^{40}$ The main machine of striation, however, is law: fixing space and turning it into points, pillars of verticality, corridors of compulsion, tight measurements of distance and propinquity, normative geometries, lines of connection that do not allow any excess to surface. Space is unfolded by law, splayed like a canvas on which legal operations take place. ${ }^{41}$ Striation is $\operatorname{logos}$, the Oedipal law, the law of the Father, law as rationality, enclosure, system and language. ${ }^{42} \mathrm{I}$ am not suggesting that Massey is unaware of striation - quite the opposite. She is fully committed to fighting against it (just as she is ready to reject pure smoothness: "envisioning space as always-already territorialized, just as much as envisioning it as purely a sphere of flows, misunderstands the ever-changing ways in which flows and territories are conditions of each other"43) and her tools are precisely the relational multiplicity flows with which she has defined space. To define striation, however, merely based on the

${ }^{40}$ Massey, For Space, p. 65

${ }^{41}$ This is what Hans Lindahl, Fault Lines of Globalisation: Legal Order and a Politics of A-Legality (Oxford: Oxford University Press, 2013), p. 18, means when he writes that "law orders space by differentiating ought-places and interconnecting them normatively, such that, first, one ought to enter and leave certain places in certain ways, and, second, certain forms of behaviour are assigned to certain places."

${ }^{42}$ see Doel, Postructuralist Geographies.

${ }^{43}$ Massey, For Space, p. 99 
political is not only to have a reductive understanding of striation, but significantly, to miss out on the legal tools that can help the political anti-hegemonic struggle.

The inclusion into the definition of the characteristics of space (and by implication, of law) that Massey rejects are important for two further reasons. First, systemic closure, textuality and even negativity are regularly generative of openness, materiality and positivity. Legal closure is a way for law to guarantee its independence from direct control by other, traditionally more visible or powerful forms of social expression, such as economics or politics. Spatial closure is a way of epistemologically and ontologically accessing space. ${ }^{44}$ Law's textuality is a problem only when it excludes the material, the embodied and spatialised. But otherwise, it has managed to help law evolve in ways that otherwise would never have. Textuality of space and the discursive turn in the humanities as a whole, has in fact precipitated the spatial turn, setting the bases for an openness to otherness. Negativity, in the sense of discontinuity of legal and spatial flow, creates a space for pause (which is the necessary complement to flow, as Deleuze and Guattari have shown) but also of awareness of limits and limitations. Whether one places these characteristics in a positive or negative context, make a difference in how these are to be understood and dealt with. And in this, I wholeheartedly agree with Massey's espousing of the Deleuzian/Bergsonian/Spinozan line of thought, that demands these to be placed on a plane of immanence where flows and pauses construct a manifold of plenitude rather than one of aporias. Yet, there is a significant place in the law/space thought productively occupied by such issues.

The second reason for which these characteristics must be included when thinking of space, is that narratives of space are also part of spatial ontology, especially if one, like

\footnotetext{
${ }^{44}$ Philippopoulos-Mihalopoulos, Spatial Justice.
} 
Massey, wants to avoid essentialization and abstraction when defining space. Space ought to be understood ontologically as both the possibility of multiplicity, interrelations and process; and the equally present possibility of uniformity, formalization of relational paths, and pause. Narratives of space as bounded remain powerful in some disciplines, and not least in law. Regardless of whether these are right or wrong, they are necessary ruptures of the open space of flows. We cannot underestimate the latter's unnerving expanse. To be out, in the open space of flow, is also to be exposed to individual and social vulnerability. ${ }^{45}$ A way of dealing with that is to erect walls, put up barriers, hide behind walls and locked doors, create spaces of pause. When defining space, we need to be aware of these needs and not to dismiss them as neoliberal, bourgeois comforts. I remember walking in Kilburn with Doreen, when a cyclist who was cycling on the pavement passed us by. He was not going fast or aggressively, and he seemed to know that he was doing something not quite right. Yet, at that moment, Massey of flows became Doreen of boundaries: she scolded him for cycling on the pavement. After my initial surprise, I understood: her reaction was indicative, beyond any doubt, of hers and everyone's need for a space where (traffic) flow is not desired. Doreen at that point called upon law (clearly on her side) to help her contain the narrative of the cyclist. She opted for pausing rather than flowing along. These days, whenever I cycle on the pavement (but mind: because it would be unsafe otherwise, and always carefully, hesitantly and ceding priority to the pedestrian!), Doreen is there to caution me.

\footnotetext{
${ }^{45}$ Philippopoulos-Mihalopoulos, "Actors or Spectators? Vulnerability and Critical Environmental Law", in Human Rights and the Environment: In Search of a New Relationship, Grear, ed. (Oñati: Oñati Socio-Legal Series, 2013).
} 


\section{Responsibility and Justice}

In this section, I would like to touch upon two intimately juridical concepts, those of responsibility and justice, which are explicitly (in the first case) and implicitly (in the case of justice) addressed by Massey. The reason I find these concepts compelling is because they allow a greater integration between law and space, if one is willing to interpret them in the spatiolegal manner I attempt below.

Massey often writes about responsibility. Her political geography project has come to full fruition early on with her influential piece on power-geometries, ${ }^{46}$ where responsibility referred mostly to the way we should be imagining a new kind of space, beyond representation, closure and stasis. Responsibility was the center of her 2004 piece Geographies of Responsibility, the main arguments of which were then expanded in For Space. Massey is influenced by Moira Gatens and Genevieve Lloyd's Spinozan take on responsibility, ${ }^{47}$ with which she agrees on at least three points:

"First, this is a responsibility which is relational: it depends on a notion of the entity (individual, political group, place) being constructed in relation to others. Second, this is a responsibility which is embodied in the way place

\footnotetext{
${ }^{46}$ Massey Power-Geometries.

${ }^{47}$ Moira Gatens and Genevieve Lloyd, Collective Imaginings: Spinoza, Past and Present (London: Routledge, 1999).
} 
is said to be embodied. And third, this is a responsibility which implies extension: it is not restricted to the immediate or the very local." 48

Although Gatens and Lloyd's emphasis is on time, Massey attempts to spatialize their thinking by linking it to distance: "Responsibility takes the form of a nested set of Russian dolls. First there is 'home', then perhaps place or locality, then nation, and so on. There is a kind of accepted understanding that we care first for, and have our first responsibilities towards, those nearest in." ${ }^{49}$ But extension, embodiment and relationality, in sum space, make connections much more complicated than simple circles of intimacy and strangeness. Massey uses London as a prime example of connectivity, which tends to prioritize the global (financially speaking) over the local.

On a spatial level, responsibility refers to the way we position ourselves (indeed, our bodies) in relation to other bodies. Responsibility is typically a juridical term. ${ }^{50}$ On a spatiolegal level, it is one of the main lawscape mechanisms for negotiating law and space. I understand responsibility as the corporeal 'response' to a noxious, ethically questionable body (a body is always collective, always an assemblage, even when belonging to one individual ${ }^{51}$ ). It is a body's responsibility to move away from a problematic assemblage, and further, proactively to stop this from carrying on. In this I

${ }^{48}$ Doreen Massey “Geographies of Responsibility”, Geografiska Annaler, 86(B1) (2004), 5-18, p. 9.

${ }^{49}$ Ibid.

${ }^{50}$ E.g., H. L. Hart, Punishment and Responsibility: Essays in the Philosophy of Law (Oxford: Oxford University Press, 2005).

${ }^{51}$ Philippopoulos-Mihalopoulos, Spatial Justice. 
am inspired by Jane Bennett's description of responsibility, ${ }^{52}$ but also from the legal understanding of responsibility that refers to both positive and negative obligations (in the sense of omission of a duty to act, say, when a life is in danger). In that sense, not only do we, as humans, have a responsibility to remove ourselves from noxious assemblages that perpetuate, say, environmental degradation, climate change denial, and rampant exploitation, but the responsibility extends to oppose to this and actively trying to stop such regimes. Massey's context of interrelations is very significant here: beyond Russian dolls, we are now faced with a planetary responsibility and indeed need to care. Our presence on the planet has made us all part of a noxious assemblage - the Anthropocene. Temporally and spatially, the new geology of the Anthropocene that describes the human as ever-present through their acts and their consequences, has brought an urgent sense of spatialised responsibility: the need to relate to the planet. Responsibility in this case is actualized through the withdrawal from assemblages that contribute to the planetary decline. There is, of course, the major issue of historical responsibility, as Gatens and Lloyd remind us. The difficulty of situating oneself responsibly in relation to a past that determines present and future cannot be underestimated. ${ }^{53}$ The answer lies in the possibility of redescribing things in a way that neither absolves a body from the responsibility of situating itself, nor inebriates this (human) body with the illusion of control of the assemblage, or indeed the whole world. The question now becomes how to take advantage of the human omnipresence and not

\footnotetext{
${ }^{52}$ Jane Bennett, Vibrant Matter: A Political Ecology of Things (Durham: Duke University Press, 2010).

53 see Amish Amin, "Collective Culture and Urban Public Space”, City 12(1) (2008), 524 , on the "ethics of the situation".
} 
be fooled by the superficial impression that to be everywhere equates to being central to everything. ${ }^{54}$

This is emphatically not a neoliberal discourse. It is not about one's individual, or even collective freedom to withdraw freely and to decide one's own fate. If there is freedom in it, it is a Spinozan freedom, namely the necessity of self-actualization of each body, rather than an expression of free will. Every body is part of a greater, collective body. Freedom in that sense, is the actualization of one's situatedness within that body. This is a distinctly collective freedom ${ }^{55}$ that operates as the enabling bondage of the responsibility of being situated with regards to other bodies. This is a distinctly spatial responsibility that requires specific corporeal spatial movements, material action and embodied decisions. Finally, this is a distinctly juridical responsibility in that it presupposes negotiations but necessarily ends up in clear-cut distinctions of the binary, almost side-taking type. Political responsibility is often thought of in parallel to morality. A juridical responsibility, however, does not have an overarching moral structure to appeal to and be determined by. Rather, it is ethical in the Spinozan way, namely localized and particular, always in process, necessarily unfolding in relation to other bodies; but also aware of the need to remain faithful to the function of binding expectations and not letting society down.

Massey's work encourages us to think of the spatiality of juridical responsibility as part of a larger conceptual framework - one with which Massey has not dealt explicitly, but which characterizes her work as a whole. This is the concept of justice, and spatial

\footnotetext{
${ }^{54}$ David Chandler, 'The World of Attachment? The Post-humanist Challenge to Freedom and Necessity', Millennium - Journal of International Studies 41(3) (2013), 516-535.

${ }^{55}$ Rosi Braidotti, The Posthuman (Cambridge: Polity, 2013).
} 
justice in particular. It is beyond doubt that Massey was preoccupied by the lack of justice, not merely in the distributive sense, but in a profoundly embodied and grounded sense. Her work on gender and space for example, ${ }^{56}$ attests amply to the need for a just understanding of gender difference and the challenges that women (still) face on the frontline between the private and the public. Or indeed the spatial injustice analyzed by The Kilburn Manifesto, ${ }^{57}$ where the local was already competing with the global - and losing.

The idea of justice as a just emplacement, namely a connection with other bodies, simultaneously and relationally, and the continuous negotiation of one's position, is paramount to Massey's work. One of her favorite examples has been the disparity between North and South England: anger about injustice was oozing through her every pore when she was talking about how the North has been essentially left to its own devices. Always in the North, but this time in the greater Manchester area, where Doreen Massey grew up and later used to visit her aging parents, the most tangible instance of spatial justice emerges in the way her father and mother were increasingly pushed out of their city by other bodies, busy and faster and threatening. This she describes as the destiny of space, "quite ordinary spaces [that] hold up a mirror which excludes you from membership." 58 In a brief but infinitely endearing text, Doreen talks about the various

${ }^{56}$ Doreen Massey, Space, Place, and Gender (Minneapolis: University of Minnesota Press, 1994).

57 Stuart Hall, Doreen Massey, and Michael Rustin, eds., After Neoliberalism? The Kilburn Manifesto (London: Lawrence \& Wishart, 2015).

${ }^{58}$ Doreen Massey, 'The Trees Will Outlast Us All', in Strangely Familiar: Narratives of Architecture in the City, Borden et al., eds. (London: Routledge, 1996), p. 76. 
bodies, human and nonhuman, that vie for the same space: affluent residents, council tenants, new council housing owners, her parents; but also airplanes that fly above, buses, garden city ideologies, protective grills against vandalism and burglary, even "trees [that] will outlast us all". ${ }^{59}$ Amongst this parade of bodies, there is a familiar one: the cyclist who cycles on the pavement.

"Young lads on bikes can terrify the life out of you. My father has devised a spatial tactic: he never walks in the middle of the pavement but always to one side (the inside edge is best) - that way you know which side of you the bikes will go." 60

This is the definition of spatial justice I would like to suggest: spatial justice is a question that emerges when two or more bodies desire to occupy the same space at the same time. ${ }^{61}$ Doreen's father and the ubiquitous cyclist vie for the same space at the same time. Is there any point of confronting a cyclist with your own frail, aged body? What are your options? Appeal to the law, of course. Point to the boundaries given to you by law: cycling on the pavement is illegal. A cyclist is a collective, technological, distinctly posthuman body, much stronger than that of an aged gentleman. The encounter is fractally repeated on various different lawscaping levels: gentrification versus existing working-class residents; air pollution versus planetary health; fish stock versus industrial fishing fleets. The list goes on, and the register often needs to change in order for an ethical solution to

\footnotetext{
${ }^{59}$ Massey, “The Trees Will Outlast Us All”, p. 76

${ }^{60}$ Massey, “The Trees Will Outlast Us All”, p. 76

61 for other definitions of spatial justice and objections to them, see PhilippopoulosMihalopoulos, Spatial Justice.
} 
be found. Existing registers, say, money-making versus environmental considerations, or relocation versus better amenities, are not always helpful since they are often co-opted and the answers prescribed. The solution is often to withdraw from the register of the particular confrontation. In the cyclist's case, the gentleman withdrew from the register of the confrontation and found a spatial path that would allow him to share that space. Withdrawal is neither passive, nor a defeat. It is a different plane of negotiation, a reoriented lawscape where bodies can be creative about opportunities for new spatial and corporeal configurations: "as the built environment shifts to respond to other desires, the consequent exclusions may themselves be identity-forming: they, too, are part of what tells you who you are." ${ }^{62}$

Just as spatial justice cannot be thought of as a closed, static affair where each body finds its perfect emplacement for eternity, in the same way it cannot be thought of as nostalgia, return to the origin, or indeed return to a land claim just because one happened to get there first. Massey is aware of this, and the message is given to us through a cake anecdote. During a visit home, Doreen and her sister were bitterly disappointed when their mother presented them, not with the tried, tested and expected, much loved chocolate cake, but a new recipe, all light and fluffy and not at all like the stodgy, wartime blend they were used to. "But with one voice my sister and I sent up a wail of complaint - 'Oh Mum...but we like the old chocolate cake."'63 Doreen lived to regret that reaction, but the incident became a valuable lesson: "when nostalgia articulates space and time in such a way that it robs others of their histories (their stories), then indeed we

\footnotetext{
${ }^{62}$ Massey, “The Trees Will Outlast Us All”, p. 76

${ }^{63}$ Massey, For Space, p. 124
} 
need to rework nostalgia." ${ }^{64}$ This is also a question of justice: claims that vie with the claims of others (through narratives but also official historical accounts) by claiming the same space in exclusion of all others, are not the way to go. We need to withdraw from such strategies.

Massey's distance from law is much more pronounced than her distance from justice. Even though she hardly ever addresses issues of justice explicitly, justice and specifically spatial justice underlines her work. But spatial justice is the spatiolegal, indeed lawscaping, concept par excellence, and as such, an entry point for Massey's difficult connection with law, and a smoother, kinder, easier connection with justice.

\section{Law after space/Space after law}

Considering law an integral, indeed unavoidable part of spatial thinking has profound consequences for both law and space. Let me offer some basic pointers of how this space opened by the lawscape, as the tautology and simultaneous difference between law and space, can be understood.

First, space should necessarily be described as both open and closed because of the various legal instruments that allow or enforce closure. While space can still be imagined as open (and indeed it must) as Massey urges us, its factual legal closure must be taken into consideration when constructing spatial strategies.

${ }^{64}$ Massey, For Space, p. 124 
Second, and a consequence of the first, law (and its characteristics as closed, textual, negative and so on) helps explain why space is, both in concept and fact, closed/textual/negative and so on. Except for offering the reason (such as property, community, national jurisdiction etc, in the service of binding expectations) for these spatial formations, law also offers a social understanding of why these formations might be deemed necessary or even desirable. This is not a justification of property regimes, community nostalgia or geopolitical exclusions. On the contrary, it is a suggestion for an integrated understanding of the polymorphy of space as a means of further changing it, according to the desires of the bodies that constitute it.

Third, law allows a deeper understanding of the power of structures that emerge when bodies move in and with space, generating different spaces and laws as they go along. Issues of path dependency (or legal precedent and social expectations of law), desire for protection (and therefore exclusion of others) to the point of security-obsessed ${ }^{65}$ and immunized ${ }^{66}$ societies, are intimately connected to a legal understanding of territory and one's perceived rights to it.

Differentiating law from politics in terms of space is also important, not least because of their different temporalities. Political action can be swifter and more immediate, indeed more rousing. But its significance will be much reduced if legal solidification in the form of legal amendments is not introduced. In order for the latter to take place, a longer, more ponderous temporality (that of law) needs to be taken into

${ }^{65}$ see Zygmunt Bauman, Community: Seeking Safety in an Insecure World (Cambridge: Polity, 2000).

${ }^{66}$ Peter Sloterdijk, In the World Interior of Capital: Towards a Philosophical Theory of Globalization (Cambridge: Polity, 2013). 
consideration, with time lags of uncertainty that may have, in turn, a political effect. All this is mirrored on, or more accurately co-constituted with, space. The spatial jurisdiction of administrative units, for example, changes across time, not just in terms of political will but, more regularly, as a 'quiet' legal change. This is important also for the way local communities are structured following changes in the law, which pass without political consent, serious consultation or struggle, and yet have a profound political effect on the spatiality of neighborhoods.

Introducing law into space brings forth the element of conflict in a more pronounced way. Conflict is more than multiplicity and interrelations. It can be much more expansive and determining, and can overshadow precisely the multiplicity that has enabled it to emerge in the first place. Understanding the role of law in the spatiality of conflict has a double effect: on the one hand, to fathom how political conflict can be filtered and possibly quelled through legal intervention; on the other, to understand epistemological ruptures in terms of narratives of belonging, and to offer the tools for a more sober albeit admittedly often inadequate dealing (such as the position of international law with regards to the Israeli settlements in the West Bank).

In turn, thought together with space, law integrates its spatiotemporal groundedness and moderates the reach of its universal and abstract narrative. Law's spatiality fleshes out law's relationality, moving away from traditional legal anthropocentrism, and bringing in posthuman considerations that normally escape law's theoretical grasp. At the same time, spatial emplacement with regards to issues of responsibility and justice becomes an opportunity for law to examine its monopoly of violence, social oppression potential, and such latent (or even overt) structures as racism, sexism and other forms of discrimination that contribute to an impression of legal neutrality even when faced with issues of structural bias, historical and current colonial 
configurations, and systematic violence. In other words, as I have commented elsewhere ${ }^{67}$ space brings in law ethical considerations that demand in their turn ethical positioning on behalf of law.

Doreen Massey has launched a new way of thinking about space. Most importantly, however, she has offered a new way of thinking about ourselves (in our posthuman, embodied collectivities) in relation to that space. Her deeply political project is visionary yet grounded, highly theoretical yet steeped into her everyday experience. What I have tried to do here is amplify this everyday experience, open up that spatial manifold and reveal law-related aspects of space that, in her visionary, optimistic and future-arresting flight, Doreen had put aside. While it is important to remain optimistic and carry on this flight of politics and space that Massey has begun, it is also important to acknowledge the various legal ways in which optimism gets clipped by law, and at the same time, to have ready the legal tools to carry this optimistic transformation.

67 Andreas Philippopoulos-Mihalopoulos, "Spatial Justice: Law and the Geography of Withdrawal", International Journal of Law in Context, 6(3) (2010), 1-16. 
